JPkM Wahana Usada Vol. 1 No. 2

\title{
PELATIHAN PEMBUATAN JAMU DAUN KATUK (SAUROPUS ANDROGYNUS) PELANCAR ASI SEBAGAI UPAYA MENSUKSESKAN GERAKAN ASI EKSKLUSIF DI KELURAHAN GUNUNG ANYAR SURABAYA
}

\author{
Iswati, Retno Setyo ${ }^{1 *}$; Marliandiani, Yefi ${ }^{2}$; Latifah, Anik ${ }^{3}$; Andarwulan, Setiana ${ }^{4}$ \\ ${ }^{1,2,3,4}$ Universitas PGRI Adi Buana Surabaya \\ *Korespondensi: retnosetyoiswati@gmail.com
}

\begin{abstract}
Background: Gunung Anyar is a village in Gunung Anyar, Surabaya Municipality. In this area the puerperal mother cannot breastfeed properly. One way to overcome this problem is to make herbal drinks from katuk leaves. Some houses in Kelurahan Gunung Anyar have enough area to plant katuk leaf seedlings. Training on making herbal drinks from katuk leaves can improve the skills of cadres and pregnant women. This activity can also build innovation and creativity in varying the utilization of katuk leaves. Method: This activity is carried out through demonstration of making herbal drinks with the target being cadres and pregnant women. Results: The results of the training were very good. All participants actively participate and can train other pregnant women to make herbal drinks from katuk leaves at home. Conclusion: Training can be done at home by pregnant and lactating mothers
\end{abstract}

Keywords: katuk's leaf, herbal medication, Gunung Anyar.

\begin{abstract}
ABSTRAK
Latar Belakang: Gunung Anyar adalah salah satu desa di kelurahan Gunung Anyar, Kota madya Surabaya. Di daerah ini ibu nifas tidak dapat menyusui secara baik. Salah satu cara mengatasi masalah tersebut adalah dengan membuat minuman herbal dari daun katuk. Beberapa rumah di Kelurahan Gunung Anyar memiliki area yang cukup untuk menanam bibit daun katuk. Pelatihan pembuatan minuman herbal dari daun katuk dapat meningkatkan keahlian kader dan ibu hamil. Kegiatan ini juga dapat membangun inovasi dan kreativitas dalam memvariasikan dalam pemanfaatan daun katuk. Metode: Kegiatan ini dilaksanakan melalui demonstrasi pembuatan minuman herbal dengan target adalah kader dan ibu hamil. Hasil: Hasil dari pelatihan sangat bagus. Seluruh peserta aktif berpartisipasi dan dapat melatih ibu hamil lainnya untuk membuat minuman herbal dari daun katuk di rumah. Simpulan: Pelatihan dapat dilakukan di rumah oleh para ibu yang hamil dan menyusui
\end{abstract}

Kata kunci : daun katuk, pengobatan herbal, Gunung Anyar.

\section{Akademi Keperawatan Kesdam 1X/Udayana}


JPkM Wahana Usada Vol. 1 No. 2

\section{PENDAHULUAN}

Air Susu Ibu (ASI) adalah cairan kehidupan terbaik yang sangat dibutuhkan oleh bayi. ASI mengandung berbagai zat yang penting untuk tumbuh kembang bayi dan sesuai dengan kebutuhannya. Meski demikian, tidak semua ibu mau menyusui bayinya karena berbagai alasan sebagai contoh: takut gemuk, sibuk, payudara kendor, dan sebagainya. Pada pihak lain, ada juga ibu yang ingin menyusui bayinya, tetapi mengalami kendala. Biasanya ASI tidak mau keluar atau produksinya kurang lancar. Nanny Vivian 2014). Memberikan ASI sesuai kebutuhan bayi berarti keuntungan untuk semua, bayi akan lebih sehat, cerdas dan berkepribadian baik, ibu akan lebih sehat dan menarik. Perusahaan, lingkungan, dan masyarakat pun akan lebih mendapat keuntungan. ASI sangat penting untuk peningkatkan SDM kita di masa yang akan datang, terutama dari segi kecukupan gizi sejak dini (Utami Roesli, 2008).

Dari hasil penelitian United Nation Child's Fund (UNICEF) dari tahun 2005 hingga 2011 didapatkan hasil bahwa bayi Indonesia yang mendapat ASI Eksklusif selama 6 bulan pertama ialah sebanyak 32\% dan didapati 50\% anak diberikan ASI Eksklusif sehingga usia 23 bulan. Tetapi persentase ini masih rendah bila dibandingakan dengan negara berkembang lain seperti Bangladesh didapati 43\% anak diberikan asi eksklusif selama 6 bulan dan 91\% anak mendapat ASI sehingga usia 23 bulan (UNICEF, 2011).

Survei Demografi Kesehatan Indonesia tahun 2012 jumlah ibu yang menyusui mencapai 42\%. Di Semarang, bayi yang mendapat ASI ekslusif hanya 40\% dan 60\% ibu tidak menyusui bayinya karena berbagai alasan kesibukan bekerja dan demi menjaga keindahan tubuhnya. Ibu rela tidak memberikan ASI eksklusif dan hanya

\section{Akademi Keperawatan Kesdam 1X/Udayana}


diberikan susu formula saja. Dalam laporan Riskesdas, pola menyusui dikelompokkan menjadi tiga kategori, yaitu menyusui eksklusif, menyusui predominan, dan menyusui sesuai definisi World Health Organization (WHO).

Salah satu cara dalam meningkatkan produksi ASI, yaitu dengan memanfaatkan tanaman disekitar. Jenis tanaman yang dapat menambah produksi ASI adalah daun katuk. Bagian tanaman katuk yang dapat dimanfaatkan adalah daun, batang, bunga, buah dan akar. Menurut Santosa, 2008 Katuk (sauropus androgynus) merupakan tanaman sayuran yang banyak didapatkan di Asia Tenggara. Banyak sebutan untuk tanaman katuk ini, seperti masyarakat Minangkabau menyebutnya dengan nama Simani, sedangkan masyarakat Jawa menyebutnya katukan atau babing. Masyarakat telah menggunakan daun katuk sebagai sayuran hijau untuk meningkatkan produksi ASI, hal ini disebabkan karena daun tersebut memiliki banyak kandungan gizi seperti protein, kalori dan karbohidrat. Selain itu katuk juga mengandung banyak vitamin A, vitamin C, vitamin B1 thiamin, mineral, lemak, tanin, flavonoid, saponin, dan alkaloid papaverin. Dengan kandungan tersebut maka tanaman katuk selain sebagai pelancar ASI juga digunakan sebagai tanaman obat tradisional.

Dalam upaya meningkatkan kualitas kesehatan ibu nifas serta memberdayakan masyarakat sekaligus menjaga kelestarian tanaman obat, maka perlu dilakukan kegiatan pengabdian masyarakat ini. Pelatih berencana memanfaatkan kegunaan dari daun katuk dalam meningkatkan produksi ASI. Biasanya daun katuk dikonsumsi dalam bentuk lalapan atau sayur rebusan. Dengan adanya pelatihan ini, daun katuk akan dikonsumsi dalam bentuk minuman segar yang siap konsumsi.

Kelurahan Gunung Anyar adalah salah satu kelurahan yang ada di kecamatan Gunung Anyar kotamadya Surabaya. Masyarakatnya terdiri dari perumahan dan 
perkampungan. Perkampungan yang masih memiliki lahan di sekitar pekarangan rumah dapat dimanfaatkan dalam budi daya tanaman daun katuk. Untuk menambah inovasi pemanfaatan daun katuk dapat dibuat dalam minuman siap minum. Minuman disimpan di dalam kulkas sehingga tidak basi setelah proses pembuatan. Maka dari itu kami perlu menginformasikan sebagai pening -katan ketrampilan kepada ibu - ibu kader maupun ibu hamil yang akan bersalin yang berlokasi di Kelurahan Gunung Anyar untuk melakukan pengabdian masyarakat dengan judul pengabdian " Pelatihan Pembuatan Jamu Daun Katuk Pelancar Asi Sebagai Upaya Mensukseskan Gerakan Asi Eksklusif Di Kelurahan Gunung Anyar Kecamatan Gunung Anyar, Kotamadya Surabaya". Tujuan dari pelatihan pembuatan jamu katuk adalah : 1 ) Meningkatkan ketrampilan ibu dan kader dalam pengolahan daun katuk melalui pelatihan. 2 ) Meningkatkan pemberdayaan penanaman daun katuk sebagai bahan pembuatan minuman botol. 3) Ibu dan kader yang mengikuti pelatihan dapat menjadi tutor dalam menularkan ketrampilan yan diperolehnya kepada peserta lain secara langsung melalui praktek di rumah.

\section{METODE}

Tahapan pengkajian data diawali dengan melakukan pendekatan kepada masyarakat kemudian menggali masalah yang ada tentang cakupan ASI Ekslusif yang belum menacapai $100 \%$. Teknik pengumpulan data dilakukan melalui wawancara dengan warga masyarakat yang memiliki anak bayi antara 0-6 bulan serta ibu hamil di trimester tiga. Selain itu juga melakukan pendekatan dengan para kader posyandu setempat. Mereka diberi pertanyaan yang berkaitan dengan masalah ASI. Setelah data terkumpul,

\section{Akademi Keperawatan Kesdam 1X/Udayana}


dengan permasalahan mengenai pemberian ASI ekslusif yang belum tercapai, peneliti melakukan pelatihan terhadap 30 orang tentang pembuatan jamu daun katuk di Kelurahan Gunung Anyar Kecamatan Gunung Anyar Kotamadya Surabaya. pelatihan yang dilakukan ini selama 3 jam dengan metode ceramah, demonstrasi dan praktek. Baik ibu hamil trimester tiga maupun para kader dilatih melakukan pembuatan jamu. Setelah selesai dilakukan pelatihan, peneliti melakukan analisis melalui praktek mandiri yang dilakukan secara langsung oleh para kader dan ibu hamil trimester tiga. Peneliti melakukan pengamatan dan observasi bila mungkin masih ada langkah yang salah, dan segera dilakukan pembenaran.

\section{HASIL DAN PEMBAHASAN}

Dari pelaksanaan pemberdayaan kepada masyarakat di wilayah kerja kelurahan Gunung Anyar Kecamatan Gunung Anyar Kotamadya Surabaya hasil yang di dapatkan, baik kader maupun ibu hamil trimester tiga mampu dalam melakukan praktik pembuatan jamu secara mandiri. Hampir seluruh peserta pelatihan jamu daun katuk mempraktikkan pembuatan jamu dengan langkah yang benar. Dari segi pengetahuan sendiri, ibu hamil dan ibu kader posyandu mampu meberikan informasi secara terinci mengenai manfaat dan cara pembuatan jamu daun katuk. Dengan demikian secara tidak langsung meningkatkan pengetahuan ibu hamil dan ibu kader posyandu. Mereka menjadi lebih tahu tentang cara pengolahan daun katuk secara benar sehingga khasiat dari daun katuk akan lebih effektif dalam meningkatkan produksi ASI. Harapannya dengan melatih 30 yang terdiri dari ibu hamil dan ibu kader posyandu, masalah ASI Esklusif akan teratasi. Tindak lanjut tentang pemberdayaan ini selanjutnya akan dilakukan pengamatan yang secara berkelanjutan. Bila memungkinkan akan diadakan

\section{Akademi Keperawatan Kesdam 1X/Udayana}


JPkM Wahana Usada Vol. 1 No. 2

pelatihan jamu yang serupa namun dengan metode atau langkah yang lain dalam pembuatan jamu. Sehingga nantinya dirasa akan lebig efisien.

\section{SIMPULAN}

Pelatihan yang dilakukan dapat meningkatkan kemampuan ibu dan kader dalam memanfaatkan tanaman daun katuk untuk meningkatkan produksi ASI. Dengan demikian produksi ASI meningkat dan ibu dapat memberikan ASI secara Ekslusif di Kelurahan Gunung Anyar

\section{DAFTAR PUSTAKA}

Kemenkes RI. (19 juni 2017) Dukung Ibu beri ASI Ekslusif. http://www.depkes.go.id/article/print/15091400003/dukung-ibu-bekerja-beri-asieksklusif.html

Nanny Vivian. 2014. Asuhan Kebidanan Pada Ibu Nifas. Jakarta : Salemba Medika.

Roesli, Utami. 2008. Inisiasi Menyusu Dini plus ASI Eksklusif, Pustaka Bunda, Jakarta

Santosa, 20 juni 2017 Definisi Daun Katuk. Diakses dari https://doclide.net/documents/jtpunimus-gdl-fajarermaw-6200-3-babii-html

Riskesdas, $\quad 22 \quad$ juni 2017 Infodatin. https://www.google.com/url/httpwww.depkes.go.idpusdatininfodatin diakses

WHO/UNICEF. Panduan Pelatihan Konseling Menyusui Modul 40 jam. WHO/UNICEF. 2011. 